\title{
Determination of uranium and thorium in water for human consumption in the county of Angra dos Reis
}

\author{
Gonçalves $^{a}$ M.F., Ferreira ${ }^{a}$ A.C.M., Carvalhal ${ }^{a}$ A.B. \\ ${ }^{a}$ Instituto de Radioproteção e Dosimetria - IRD, 22783-127, Rio de Janeiro, RJ, Brazil \\ mary.fg@hotmail.com
}

\begin{abstract}
Studies indicate that the presence of uranium and thorium radionuclides in the environment are of great importance in monitoring radiation levels. Humans can have a direct or indirect exposure. The radiological impact for the members of the population living in Angra dos Reis - RJ was evaluated using environmental monitoring data of uranium and thorium in water for human consumption of the county of Angra dos Reis. Monitoring data showed concentrations much lower than the guidelines based on the maximum permitted value of uranium in waters for consumption established by Ministry of Health and CONAMA. Thorium is the most significant radionuclide, however it is important to note that for a dose calculation several radionuclides must be taken into account, but for this work only U-238 and Th-232 were considered. The public that lives in the county of Angra dos Reis is not exposed to the radiation that would result in a radiological impact.
\end{abstract}

Keywords: environmental monitoring, water, uranium, thorium, Angra dos Reis. 


\section{INTRODUCTION}

The artificial radionuclides released by nuclear power plants have a very small contribution regarding the dose of radiation received by the population, with the natural radioactivity being the largest contributor [1].

Environmental radiological monitoring is of utmost importance for determining levels of radioactivity and for evaluating doses in the population. This monitoring assesses possible impacts to the environment and the public.

In Brazil, one of the places that presents environmental monitoring is the county of Angra dos Reis, which aims to analyze the possible impacts caused by the operation of the power plants around the "Almirante Álvaro Alberto Nuclear Power Plant" (CNAAA). Currently, two nuclear power plants operate in Brazil, Angra 1 and Angra 2, with a third one under construction (Angra 3), which was scheduled to operate in 2014. The power plants are located on the Itaorna beach, in Angra dos Reis, approximately $130 \mathrm{~km}$ of the city of Rio de Janeiro, which is an important region for tourism, fishing and ecological points of view [2,3].

Although the Central Nuclear (CNAAA) has an environmental control program, accompanied by the inspection bodies (IBAMA / CNEN), the city of Angra dos Reis is concerned with monitoring, radiologically, the water collection points to add to the monitoring already carried out by it (bacteriological and chlorine), providing more information on water quality for the local population, maintaining the transparency even of natural radionuclides, which usually have a greater influence on the population than the artificial ones released by the power plant.

The study was carried out in partnership with the Health Secretariat of Angra dos Reis, which has 102 registered points of water supply distributed in the four districts of the Municipality of Angra dos Reis, and which were the same points used in this work. In November 2018, water for human consumption was collected in the district of Angra dos Reis. The samples were collected from taps or sources, in places of public access, outside the perimeter of the Angra dos Reis nuclear power plant, "Almirante Álvaro Alberto Nuclear Power Plant" (CNAAA). The numbers of points collected in each district are: 26 in the first district, 24 in the second district, 25 in the third district and 
27 in the fourth district. It is important to note that Ilha Grande District was not included in this study due to time and access limitations.

Thus, the present study proposes to carry out a survey of natural radionuclides (U-238 and Th232) contents in the water supply through the analysis of the inductively coupled plasma mass spectrometry (ICP-MS) and later, calculate the doses received by the members of the public due to water intake, and from the results obtained, present information that can be used for a diagnosis of the situation of water resources in the county of Angra dos Reis, as well as for the establishment of region's water background.

This study is part of a larger work where other elements will be evaluated. But for this work only U-238 and Th-232 are used, as they are two radionuclides from the main radioactive series, and in a later work other radionuclides, such as Ra-226, Ra-228 and Pb-210, will be taken into account.

\section{MATERIALS AND METHODS}

On the day after the samples were taken, they were sent to the Department of Environmental Analysis (DIRAD) at the Institute of Radioprotection and Dosimetry (IRD). The samples were filtered by a peristaltic pump and membrane with porosity of 0.45 micrometer and then acidified ( $1 \mathrm{~mL}$ of nitric acid supra pure 16 Molar), in order to avoid the loss of the constituents to be determined by adhesion to the walls of the containers, and then placed in polyethylene containers for inductively coupled plasma mass spectrometry analysis (ICP-MS).

\subsection{Inductively coupled plasma mass spectrometry analyze}

The analyses were done in DIRAD laboratory, located inside Institute of Radioprotection and Dosimetry, using a PerkinElmer ICP-MS model NexION ${ }^{\mathrm{TM}} 300 \mathrm{D}$ operating with high purity argon. Triplicates of each sample were made.

To execute the Performance Test the solution IRD 814-5051 (Be-Ce-Fe-In-Li-Mg-Pb-U 1 $\mu$ g.L ${ }^{-}$ ${ }^{1}$ ) was inserted in the equipment. The calibration solutions were produced using the multi-element solutions from the stock: PE2 (Ce-Dy-Er-Eu-Gd-Ho-La-Lu-Nd-Pr-Sm-Sc-Tb-Th-Tm-Y-Yb), PE3 (Al-As-Ba-Be-Bi-Ca-Cd-Co-Cr-Cs-Cu-Fe-Ga-In-K-Li-Mg-Mn-Ni-Pb-Rb-Se-Na-Ag-Sr-Tl-V-U- 
Zn) and PE5 (B-Ge-Mo-Nb-P-Re-S-Si-Ta-Ti-W-Zr), which resulted in a solution with $10 \mu \mathrm{g} . \mathrm{L}^{-1}$ of each element, besides a solution of the internal standard, Talium $200 \mu \mathrm{g} . \mathrm{L}^{-1}$, all from Perkin Elmer. The concentrations of the calibration curve ranged from 0 to $1.0 \mu \mathrm{g} . \mathrm{L}^{-1}$. The calibration solutions were prepared with $\mathrm{HNO}_{3} 2 \%$, in order to avoid the precipitation of the standards, since the matrix of the curve is aqueous.

The calibration curve for uranium and thorium was performed. The validation of these curves was done with the participation of the National Intercomparison Program (PNI). The result of the intercomparison presented a deviation of less than $10 \%$, compared to the previously known value, thus it was possible to perform determinations by ICP-MS. In order to increase the reliability of the results and to certify the absence of contamination, readings of the blanks from the calibration curve were made, being ideal close to $0 \mu \mathrm{g} \cdot \mathrm{L}^{-1}$.

\subsection{Dose evaluation}

The doses received by the members of the public can be calculated using the measurements of radionuclide concentrations to which the individual is exposed, which can occur through inhalation, contact or ingestion, with water ingestion being the only case considered in this work.

The calculation used considers the dose received by an exposed adult living in the sampling sites of each district. The exposed adult is defined as an adult member of the public receiving the highest dose of each district. This individual is presumed to remain in this location 24 hours a day, 365 days a year, drinking 2 liters of water per day, which is affected by the releases of radionuclides in those places.

In this work, the calculation of the dose, via water ingestion, was performed using the maximum concentrations of radionuclides, uranium (U-238) and thorium (Th-232), measured in the samples. The consumption rates used are based on the reference man of the ICRP (International Commission on Radiological Protection).

The effective dose for uranium and thorium due to ingestion was calculated using the following equation 1.

$$
D_{I N G}\left(S v \cdot y^{-1}\right)=U_{W} x C_{W} x F D C_{I N G}
$$


Where $\mathrm{D}_{\mathrm{ING}}$, effective dose due to water intake; $\mathrm{U}_{\mathrm{W}}$, annual consumption of water by an individual $\left(\mathrm{L} . \mathrm{y}^{-1}\right) ; \mathrm{C}_{\mathrm{W}}$, concentration of radionuclide in water $\left(\mathrm{Bq} . \mathrm{L}^{-1}\right)$; DC, dose conversion factor for radionuclide ingestion (Sv.Bq ${ }^{-1}$ ), according to CNEN Regulatory Position 3.01/12:2020 [4].

\section{RESULTS AND DISCUSSION}

\subsection{Inductively coupled plasma mass spectrometry analysis}

The highest and lowest concentrations of uranium and thorium in each district are highlighted in Table 1.

Table 1: Range of uranium and thorium concentrations in each district.

\begin{tabular}{|c|c|c|c|c|}
\hline $\begin{array}{c}\text { Concentration } \\
\left(\mu \mathrm{g} . \mathrm{L}^{-1}\right)\end{array}$ & First District & Second District & Third District & Fourth District \\
\hline Uranium $\left({ }^{238} \mathrm{U}\right)$ & $0.006-0.142$ & $0.016-0.082$ & $0.002-0.020$ & $0.008-0.126$ \\
\hline Thorium $\left({ }^{232} \mathrm{Th}\right)$ & $0.004-0.066$ & $0.004-0.402$ & $0.002-0.023$ & $0.004-0.210$ \\
\hline
\end{tabular}

Comparing the uranium concentrations found, they did not exceed the reference level of 30 $\mu \mathrm{g} . \mathrm{L}^{-1}$ adopted by Ministry of Health regarding radioactivity [5]. For thorium, although there is no concentration established by CONAMA, the values found are within the range of 0.01 and $1.0 \mu \mathrm{g} . \mathrm{L}^{-}$ ${ }^{1}$, determined by the literature for surface and groundwater. [6].

The uranium and thorium activity concentrations of all the analyzed points ranged from 0.002 to $0.142 \mu \mathrm{g} . \mathrm{L}^{-1}$ and 0.002 to $0.402 \mu \mathrm{g} . \mathrm{L}^{-1}$, respectively.

\subsection{Dose evaluation}

Uranium and thorium radionuclides were detected in very small amounts, and even at very low levels, thorium is the most significant radionuclide in the samples. In order to calculate the effective doses, the consumption of $2 \mathrm{~L} . d a y^{-1}$ of water per individual was considered and the dose conversion factors for $\mathrm{U}-238$ and Th-232 ingestion were $4.5 \times 10^{-8}$ and $2.3 \times 10^{-7} \mathrm{~Sv}^{-\mathrm{Bq}^{-1}}$, respectively, according to ICRP publication 119 and CNEN Regulatory Position 3.01/11:2011 [7,8]. 
Table 2 shows only the values of the highest and lowest effective doses of each district.

Table 2: Values of effective doses of water intake from each district.

\begin{tabular}{ccccc}
\hline $\begin{array}{c}\text { Effective dose } \\
\left(\mathbf{m S v} \cdot \mathbf{y}^{-\mathbf{1}}\right)\end{array}$ & First District & Second District & Third District & Fourth District \\
\hline Lowest value & $2.63 \times 10^{-6}$ & $3.05 \times 10^{-6}$ & $1.37 \times 10^{-6}$ & $2.97 \times 10^{-6}$ \\
Highest value & $4.48 \times 10^{-5}$ & $2.75 \times 10^{-4}$ & $1.60 \times 10^{-5}$ & $1.44 \times 10^{-4}$ \\
\hline
\end{tabular}

The radiation dose from water ingestion ranged from $1.37 \times 10^{-6}$ to $2.75 \times 10^{-4}\left(\mathrm{mSv}_{\mathrm{y}} \mathrm{y}^{-1}\right)$. Thus, all samples presented values lower than the reference level of $1 \mathrm{mSv} \cdot \mathrm{y}^{-1}$ recommended by the CNEN Regulatory Position 3.01/12:2020 and even, were below the investigation level of $0.1 \mathrm{mSv}^{-1} \mathrm{y}^{-1}$, according to the CNEN Regulatory Position 3.01/12:2020 and the World Health Organization (WHO) $[4,9]$. Water can be consumed without the need to be investigated when it has values below $0.1 \mathrm{mSv} \cdot \mathrm{y}^{-1}$ [4]. The effective dose values found in each district may be associated with the path the water makes to reach each collection point. The differences between the concentrations of radionuclides in the waters in each district are related to the type of rock, its contents in the rock, the chemical characteristics of the water and the individual characteristics of uranium and thorium [6].

\section{CONCLUSION}

The concentrations of uranium and thorium showed values well below the reference values, as expected. So it is possible to affirm that the presence of these radionuclides in the collected water samples is natural and with levels that are not harmful to health. In general, the radionuclides present in the collected water are mainly of natural origin, due to the minerals of the rocks and dissolution of gases. Based on the results, the presence of radionuclides in the water samples is due to the nature of the water in the districts and not to the existence of the nuclear power plant. It was possible to know the values of two natural radionuclides in the waters of the region and in case of an accident, this work can be used as a reference due to the establishment of the region's water 
background. The public residing in the four districts analyzed is not exposed to radiation levels, due to water ingestion, which would result in a radiological impact, since the results of uranium (U-238) and thorium (Th-232) doses in the waters collected do not exceed $0.1 \mathrm{mSv} \cdot \mathrm{y}^{-1}$.

For a more complete analysis of the concentration of activity and the dose rate received by the public in these areas, a study taking into account other radionuclides is being carried out. 


\section{ACKNOWLEDGMENT}

The authors thank the Department of Environmental Analysis (DIRAD) for the opportunity to carry out this work. Angra dos Reis health's department, mainly Adriana Belmiro de Oliveira, Julio Cesar Toledo de Almeida and Marise Paulina da Silva Alves Cunha for the help in collection of all samples. To José Antonio Gonçalves for the transport of samples. To CNEN for granting the scholarship. To Igor Caldeira Pinto and Yannick Schneider Cukierman for review.

\section{REFERENCES}

[1] UNSCEAR - United Nations Scientific Committee on the Effects of Atomic Radiation. United Nations Scientific Comittee on the Effects of Atomic Radiation report to the General Assembly New York (United Nations), 1982.

[2] CARDOSO, S.N.M.; TAVARES, P.G.; BARBOZA, E. A monitoração radiológica ambiental da Central Nuclear Almirante Álvaro Alberto, In: CONGRESSO BRASILEIRO DE QUÍMICA, 2011, São Luís, Maranhão.

[3] GOMES, F. C.; GODOY, J. M.; GODOY, M. L. D. P.; CARVALHO, Z. L.; LOPES, R. T.; SANCHEZ-CABEZA, J. A.; OSVATH, I.; LACERDA, L. D. Geochronology of anthropogenic radionuclides in Ribeira Bay sediments. Journal of Environmental Radioactivity, v. 102, n. 9, p. 871-876, 2011.

[4] CNEN - Comissão Nacional de Energia Nuclear. Níveis de Investigação e de Referência para Radioatividade em Água Potável. CNEN NN 3.01 / PR 012:2020, 2020. 7p.

[5] MS - Ministério da Saúde. Procedimentos de controle e de vigilância da qualidade da água para consumo humano e seu padrão de potabilidade. Portaria MS $\mathrm{n}^{\circ} .2 .914,2011,34 \mathrm{p}$.

[6] LAURIA, D. C.; VEIGA, L. H. S.; FRANKLIN, M. R. Radioatividade em água potável: Ocorrência, regulamentação e aspectos de proteção radiológica. Instituto de Radioproteção e Dosimetria. Rio de Janeiro, 2014.

[7] ICRP - International Commission on Radiological Protection, Compendium of Dose Coefficients based on ICRP Publication 60. ICRP Publication 119. Ann. ICRP 41, 2012. 
[8] CNEN - Comissão Nacional de Energia Nuclear. Coeficientes de Dose para Exposição do Público. CNEN NN 3.01 / PR 011:2011, 2011. 101p.

[9] WHO - World Health Organization. Guidelines for Drinking-water Quality, Fourth Edition. WHO: Geneva, 2011, 564p. 